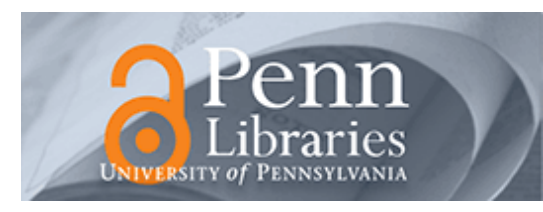

University of Pennsylvania ScholarlyCommons

1990

\title{
Toni Morrison: The Struggle to Depict the Black Figure on the White Page
}

Timothy B. Powell

University of Pennsylvania, tipowell@sas.upenn.edu

Follow this and additional works at: http://repository.upenn.edu/rs_papers

Part of the African American Studies Commons, Literature in English, North America

Commons, Literature in English, North America, Ethnic and Cultural Minority Commons, Religion

Commons, and the United States History Commons

\section{Recommended Citation}

Powell, Timothy B., "Toni Morrison: The Struggle to Depict the Black Figure on the White Page" (1990). Departmental Papers (Religious Studies). 11.

http://repository.upenn.edu/rs_papers/11 


\title{
Toni Morrison: The Struggle to Depict the Black Figure on the White Page
}

\begin{abstract}
This problem of how to represent the black self on the white page, how to overcome the inherent ethnocentrism of the Western literary tradition, is one with which both the critic and the novelist of AfroAmerican literature must struggle to come to terms. As Gates points out, it is a tradition which dates all the way back to Plato's metaphor of the soul -of a white horse which is described as a "follower of true glory" and another, "of a dark color," which in turn attempts to lead the soul "to do terrible and unlawful deeds." For those who are able to control the dark horse and allow the white one to lead the way, Plato promises a vision of the soul which goes on to "live in light always," whereas those charioteers who cannot control the black horse are condemned "to go down again to darkness," to a life below the earth.
\end{abstract}

\section{Keywords}

Philosophical object, African American culture, White people, Novels, Graphic logos, Literary criticism, Slaves, Mothers, Black communities, Textual criticism

\section{Disciplines}

African American Studies | Literature in English, North America | Literature in English, North America, Ethnic and Cultural Minority | Religion | United States History 


\section{Toni Morrison: The Struggle to Depict the Black Figure on the White Page}

\section{Timothy B. Powell}

The problem, for us, can perhaps be usefully stated in the irony implicit in the attempt to posit a "black self" in the very Western languages in which blackness itself is a flgure of absence, a negation. Ethnocentrism and "logocentrism" are profoundly interrelated in Western discourse as old as the Phaedrus of Plato, in which one finds one of the earliest figures of blackness as an absence, a figure of negation.

-Henry Louis Gates, Jr. (7)

This problem of how to represent the black self on the white page, how to overcome the inherent ethnocentrism of the Western literary tradition, is one with which both the critic and the novelist of Afro-American literature must struggle to come to terms. As Gates points out, it is a tradition which dates all the way back to Plato's metaphor of the soul - of a white horse which is described as a "follower of true glory" and another, "of a dark color," which in turn attempts to lead the soul "to do terrible and unlawful deeds." For those who are able to control the dark horse and allow the white one to lead the way, Plato promises a vision of the soul which goes on to "live in light always," whereas those charioteers who cannot control the black horse are condemned "to go down again to darkness," to a life below the earth.

It is this symbology of light and dark, in which blackness becomes the archetype of absence, negation, even evil, which must be overthrown if the "black self" is ever to become understood as presence, affirmation, and good. For centuries blacks in America have effectively undercut the white logos by "signifying," or playing upon the meanings of the traditional (white) understanding of the Word. Forced to live in a state of incarceration wherein they could not express themselves explicitly, the earliest

Timothy B. Powell is a doctoral candidate at Brandeis University. 
black Americans were impelled to adopt a dualistic and duplicitous form of the white man's language which would allow black meanings to be secretly imbued in the language of the Master. In The Souls of Black Folks, W. E. B. Du Bois tells of how slaves were able to turn the words of their oppressors' own songs against them with "veiled and half-articulate messages." In spirituals like "Swing Low Sweet Chariot," it would be clear to the slaves that the "home" to which the chariot carries the listener is not the tranquil green pastures of the twenty-third psalm, or even Plato's realm of eternal light, but instead the original home of the slaves-Africa, and the promise of freedom which that continent has held for generations of black Americans. For the soul which drives the spirituals is distinctly different from that of Plato's chariot. This "chariot" is not led on by a pure white steed towards a pure white reward but is instead a vehicle for black meaning.

What remains is to bring these meanings to the fore. In the time of slavery the black logos (the reasoning, the logic, the Word of black American culture) necessarily had to remain hidden in the semantic shadows of the Master's language. Sadly, for a long time after the Emancipation Proclamation, the black self was still confined to the shadows, the black logos to nuance. Houston Baker, in his book Blues, Ideology, and Afro-American Literature, has aptly captured this phenomenon in the critical phrase black $(w) h o l e$. For it is precisely in a hole on the edge of Harlem where the protagonist of Ralph Ellison's Invisible Man eventually finds his wholeness: "The point is that I found a home-or a hole in the ground, if you will" (Ellison 6). Whether it is literally a hole in the ground in which the protagonist finds his wholeness, as in Richard Wright's "The Man Who Lived Underground," or the kind of shadowy hole in which Bigger Thomas finds himself at the end of his quest for wholeness in Native Son, Houston Baker's phrase captures the experience of a generation of Afro-American novelists who have struggled to overcome the dilemma of how to inscribe the black self on the white page. For these are novels and stories of souls who chose to allow the black horse to lead, only to find, as the white logos dictates, that their way leads "down again to darkness," to a life under the earth.

The battle becomes, for the critic and novelist of Afro-American literature, to de-center the white logos, to create a universe of critical and fictional meanings where blackness will no longer connote absence, negation, and evil but will come to stand instead for affirmation, presence, and good-a struggle for the right/write/rite of Afro-American literature to exist. It is for this 
reason that critics like Henry Louis Gates and Houston Baker have directed us back to the vernacular, for if the black logos can be said to exist at all it must lie in oral texts like spirituals, blues, and folktales. The task which lies ahead, to my mind, is to lift the black self out of the hole, to bring black meanings out of the semantic shadows of the Master's language and to affirm these meanings in a medium which can truly be called a black text, a text whose margins are ruled by the black logos.

No one, to my mind, has accomplished this more fully than Toni Morrison. Her triumph has not come without a struggle, and it is this ongoing quest over the course of her first three novels which I will attempt delineate here. From the pain and dissimulation chronicled in The Bluest Eye (1970), to the grief and sadness of Sula (1974), Toni Morrison embarks on a journey which ends with the soaring affirmation of black selfhood in the last lines of Song of Solomon (1977). It is a quest not only to de-center the white logos but finally to rebuild the center, to dis-cover the powers which lie hidden in the black logos. In the course of discussing these three novels, I will attempt to show how Morrison rises out of what Houston Baker calls the black (w)hole to create what I will call, in a signifying riff on Baker's term, a (w)holy black text.

Ironically Morrison's quest for the black logos begins with the consummate example of the white text-the Dick-and-Jane reader:

Here is the house. It is green and white. It has a red door. It is very pretty. Here is the family. Mother, Father, Dick, and Jane live in the green-and-white house. They are very happy. ... . See Mother. Mother is very nice. Mother, will you play with Jane? Mother laughs. Laugh, Mother, laugh. See Father. He is big and strong. Father, will you play with Jane? Father is smiling. Smile, Father, smile. (7)

It is, however, a highly significant beginning, since it points to the fact that all Afro-American writers have, willingly or not, been forced to begin with the Master's language. The Dick-andJane reader comes to symbolize the institutionalized ethnocentrism of the white logos, of how white values and standards are woven into the very texture of the fabric of American life. And for the protagonist of Toni Morrison's first novel, Pecola Breedlove, it is precisely these standards which will lead to her tragic decline.

The all-too-familiar lines of the Dick-and-Jane primer also serve as an important contrast, pointing out an essential difference between the cold, clear logic of the white text and the often irrational pain of the black text which is to follow. In Langston Hughes's poem "Theme for English B," the poet asks the white instructor, "So will my page be colored that I write?" Hughes's answer is ambiguous -"Being me, it will not be white. / But it will 
be / a part of you, instructor, / you are white" (640)-intimating that the black poet's page will indeed be different and yet also suggesting that it is not possible to ever fully avoid the influence of the white instructor. It is the same question which Morrison puts before us at the outset of The Bluest Eye. For here again we are confronted with the white instructor-the essential text from which we all learned to read. By prefacing the novel, and subsequent chapters within the novel, with the text of the elementary Dick-and-Jane reader, and self-consciously juxtaposing this original or primary white text with her own black text, Morrison is presenting the reader with a challenge, calling immediately into question not only the difference between the white and black text but also how we as critics are going to read what follows.

While the anonymous author of these children's books never explicitly states that these cardboard characters are white, it is nevertheless clear, since the mythos which they embody ("Here is the family. Mother, Father, Dick, and Jane live in the green-andwhite house. They are very happy") is so clearly the ideal of Western culture, which is to say white culture. The happiness which is to be taken for granted within the family structure of this (white) family stands in stark contrast to the pain and dissimulation which defines the family life of Pecola Breedlove, one of the central characters in Morrison's "black text." Pecola's family has been ripped apart by alcoholism and anger. There never was a Breedlove house, let alone a "green-and-white" one wallpapered with happiness. The Breedloves are renters, and when Cholly Breedlove, Pecola's father, lands himself in jail, the Breedloves are put outdoors, a condition which Morrison sees as a definitive margin marking the edge of the precipice on which these black families find themselves precariously situated:

There is a difference between being put out and being put outdoors. If you are put out, you go somewhere else; if you are outdoors, there is no place to go. The distinction was subtle but final. Outdoors was the end of something, an irrevocable, physical fact, defining and complementing our metaphysical condition. Being a minority in both caste and class, we moved about anyway on the hem of life, struggling to consolidate our weaknesses and hang on .... (18)

It is interesting to note, in terms of Toni Morrison's project to dis-cover the black logos, that the "hem of life" on which Pecola and Claudia find themselves is measured here relative to a white center, or an ethnocentric standard. This is not a novel which inscribes its circle of significance around a black center, but instead offers a view of "being a minority" forced to define itself in terms of the ethnocentrism of white culture. Therefore, when Morrison writes here of "our metaphysical condition," she does 
not refer to a uniquely black metaphysical standard but is in fact speaking of "our . . . condition" relative to the "metaphysical" paradigm (or what Derrida calls the white mythologyl) of Plato and the rest of Western culture. That the black and Western paradigms are inherently different is, I think, implicitly suggested when Morrison notes that it is a "physical" (as opposed to metaphysical) "fact" which defines "our . . . condition." The ethereal, Platonic mythos of truth and goodness is a promise remote and inaccessible to this black family faced with the corporeal concerns of having to spend the night sleeping on the cold, hard ground.

And yet one is always aware in The Bluest Eye of the haunting presence of that singular (white) eye of the title, the view from the center which keeps these black characters feeling as though they have been consigned to live on "the hem of life." For example, when Pecola menstruates for the first time and Claudia and Frieda take her outside to hide the mysterious accident from their mother, there are the "fascinated eyes in a dough-white face" of their neighbor Rosemary, who immediately rushes to tell Mrs. MacTeer that "Frieda and Claudia are out here playing nasty!" " (27). And when Pecola strolls down to the neighborhood candy store, she confronts, in the eyes of the white shopkeeper, that glare of "glazed separateness" which she has felt "lurking in the eyes of all white people" (42), making her feel ugly and unwanted. For Cholly Breedlove, Pecola's father, these cruel blue eyes intervene in the form of two hunters, shining their flash lights on his nakedness as he is caught in the midst of his first sexual encounter. The anger and humiliation which boils up in Cholly is never reconciled, and his hatred becomes displaced through transference: "For some reason Cholly had not hated the white men; he hated, despised, the girl" (37). Like Cholly, Pecola's mother also comes to see herself through blue eyespreferring the identity which her white employers give to her, as the "ideal servant" who always keeps their house in orderrather than acknowledge the emotional ruins of her own life: her brutal marriage to Cholly and her cruel relationship with her own daughter, into whom she beats a "fear of life" (102). By looking at themselves through the eyes of a white culture, the Breedlove family lose all notion of their own black identity: "It was as though some mysterious all-knowing master had given each one a cloak of ugliness to wear, and they had each accepted it without question" (34).

Despite the fragility of her characters' self-images, Morrison has not failed, here in her first novel, in her quest to posit a 
black self. The Bluest Eye is meant to be a novel of failure; it is a portrait which depicts how a young black woman's idea of what constitutes a true self is de-centered by the implicitly ethnocentric tenets of the society into which she is born. Pecola Breedlove fails to discover a true self precisely because she allows her values to be dictated by the white mythology. As Claudia says, "All the world had agreed that a blue-eyed, yellow-haired, pinkskinned doll was what every girl child treasured. 'Here,' they said, "this is beautiful, and if you are on this day "worthy" you may have it" " (20). But whereas Claudia rebels against the dictates of the white mythology, destroying and dismembering the dolls she is given for Christmas, Pecola allows herself to be wooed (finally into insanity) by the dream of the bluest eye, a panacea for all of her earthly woes. She becomes convinced that, if only she had blue eyes like the painted, all-too-cheerful eyes of Shirley Temple which stare back at her each morning from her milk mug, then she too would be accepted into the world of "green-and-white" houses and families that are "very happy" which has been promised to her in the "white text" wherein she first learned to read about the world. Shirley Temple, Dick and Jane, the blonde.Christmas dolls - these are the embodiments of the white logos, the templates which society holds up for Pecola to judge herself against. These figures of the white mythology to which she compares herself are the catalysts which precipitate Pecola's psychic disintegration, leaving her alienated from any sense of an authentic black self.

In terms of Morrison's quest to inscribe the black figure on the white page, to raise her characters out of the black (w)hole, The Bluest Eye can be seen as a direct confrontation with the white logos, a necessary first step towards clearing the way for the (w)holy black text to appear. For it is Morrison's shattering contrasts between the "big and strong," "smiling" Father of the white text and broken-spirited Cholly, the father in the black text, which make clear the inadequacies of the white mythology for representing the black self. Morrison literally is deconstructing the essential white text, removing capitalization, punctuation, and finally the spacing until the white text is nothing more than a fragmentation of its former self at the beginning of the chapters:

\section{SEEFATHERHEISBIGANDSTRONGFATH HERWILLYOUPLAYWITHJANEFATHER ISSMILINGSMILEFATHERSMILESMILE (105)}

The deconstruction of the white text complete and the black text clearly differentiated, Morrison is then able to move on to the 
greater challenge of attempting to affirm blackness as present and valuable, to write the black logos.

In Sula, Morrison attempts to move her focus outside the sphere of influence of the white logos by centering her novel around a black community. Gone are the "fascinated eyes in a dough-white face" which belittle and demean the black self. By conscientiously removing these white eyes, Morrison brings into focus a world which revolves around a black cultural center, a community which is governed by black mythology. And yet she is not quite able, in her second novel, to wrench herself and her characters free from what Jacques Derrida calls "the imperialism of the logos." For even though the plot of the novel unfolds in a small Midwestern town which is inhabited solely by black folk, the tyranny of the white logos and the power which it exerts through its ability to name remain strongly, if implicitly, present. The town is called "the Bottom," and the origin of its name comes, Morrison writes, from "A joke. A nigger joke." A "good white farmer" promises freedom and "a piece of bottom land" to his slave, provided the slave performs a particularly difficult task. Once the slave has complied, instead of delivering a plot of fertile valley property, the farmer gives the black man his freedom and a tract of land " "high up in the hills." "When the slave queries his master on the name Bottom, the white man tricks him, justifying his actions by explaining that, yes, the land is high up in the hills, "but when God looks down, it's the bottom. That's why we call it so. It's the bottom of heaven-best land there is" " (5).

More than just a malevolent prank at the expense of a presumably uneducated slave, Morrison's anecdote is an insightful testimony as to how blacks have been manipulated by the white logos. The black slave is disenfranchised of the fertile valley land that should rightfully be his, not because of his ignorance but because of the duplicity inherent in the white man's logic and language, that controlling power which the white man wields in the form of the logos. The slave is in no position to argue, since it is a verbal contract to which he has committed and the logos (i.e., law, logic, word) is controlled by the white master. The final irony is that, when the valley community becomes economically prosperous enough to be able to move from an agrarian to a service-oriented society, the whites buy back the elevated property and the blacks once again wind up on the bottom. The moral of the story is, of course, that the dominance of white society has not been halted by the eradication of slavery or the 
advent of civil rights, since neither of these actions dispels the primacy of logocentrism in Western civilization.

In "The Quest for Self," Dorothy H. Lee has correctly noted that each of Morrison's novels embraces the theme of the main character's search for identity. As Lee points out, Sula is, like The Bluest Eye, the story of a failed quest, a tale of Sula's inability to create for herself a true sense of self-worth. She loses Nel, her childhood friend in whom she sees another "version of herself," through her own callous and self-centered desire for satisfaction when she takes Nel's husband to bed. Later she loses her lover Ajax, the man who sets her free from her endless wandering from man to man, ironically, because Ajax senses that his own freedom is in danger from her obsessive love. She dies, finally, unable to fulfil her quest, unable to find and hold onto a truly black self.

Again and again in Sula, Morrison returns to the image of the river with a "closed place" in the middle. The initial significance of this figure relates to an episode early in Sula's life in which she and Nel are playing along the banks of the river, swinging a young boy around and around by the arms when accidently his hands slip away and he is hurled into the muddy water. Unable to swim, Sula and Nel watch helplessly as the boy's black head disappears beneath the water and the river embraces him, leaving a dark "closed place in the water" (52). As the novel wears on and Sula's life is lived out in its recurring patterns of loss and despair, this "closed place" becomes an image of the void within Sula, of the absence at her very center, for as Morrison writes, "she had no center, no speck around which to grow" (103). Thus, in the final analysis, it becomes clear that, although Sula is a novel centered around black people and black culture, the power of the white logos is still very much in evidence. Blackness is still being used here to mean absence or negation: Black center is read here as "no center."

In her first two novels, Toni Morrison seems to reside within the critical sphere inscribed by Houston Baker's term black $(w) h o l e$, for both novels describe a search for wholeness in the shadowy periphery of a society dominated by the white logos. And yet to attempt to apply the term black (w)hole critically to Sula or Pecola is to miss much of Morrison's irony. Unlike the Invisible Man who, with a pride born of struggle, calls his hole on the edge of Harlem "home," or Bigger Thomas who, in digging himself into the hole in which he finds himself at the end of the novel, at least feels that he has succeeded in temporarily asserting his manhood, neither The Bluest Eye nor Sula is meant 
to claim that the situation of their respective protagonists is to be construed as wholeness. Pecola's and Sula's quests for identity are of ironic proportion, with no heroes, no victories, no redemption.

And yet the movement from "on the hem of life" to "no center" is, in the context of Toni Morrison's own project to write the black logos, a step forward. Unlike the great novels of Ellison and Wright, Morrison does not ask the reader to accept these characters as being portraits of black (w)holeness.2 Sula Peace's quest for identity ends, like Pecola Breedlove's, in frustration. Both of these characters, like the town in which Sula grew up, have been ironically (and rather heavy-handedly) misnamed, for they know neither peace nor love, only struggle and alienation. They are not whole, but fragile and fragmented. And yet if the critical reader is able to accept the logic of Morrison's projectthat is to say, to take an active part in un-learning the white logos -, then it becomes possible to see this move from a white center to "no center" as progress, for in doing so Toni Morrison has rejected the compromise implicit in the term black (w)holethe idea that wholeness is possible, provided the black self is willing to remain confined to the shadowy realm of basements in Harlem or abandoned tenements in Chicago.

In Song of Solomon, Toni Morrison continues her ongoing quest to free herself and her characters from the imperialism of the white logos. Like Sula, the novel begins in a black community ("the part of the world that mattered") in which blackness is still judged by the standards of the white logos, which is to say as absence, negation, and evil. The protagonist's subservience to the white logos is symbolized by his name. Milkman has been marked with the brand of the white logos at birth-given the name Macon Dead III. It is a familial scar inherited from his grandfather who, upon emancipation from slavery, was mischristened by a drunken Yankee soldier who grossly reinterpreted his grandfather's statement that he was born in Macon, Georgia, and that his father was dead. The black community attempts to signify away the brand by renaming the boy Milkman, although this name too is stultifying in that it originates out of an incident in which his mother is caught weaning her only son well past the age when city blacks consider a child sufficiently grown to feed himself. Both names arrest Milkman's maturation. Incarcerated within this linguistic prison, he dreams despondently of

some ancestor, some lithe young man with onyx skin and legs as straight as cane stalks, who had a name that was real. A name given to him at birth with love and seriousness. A name that was not a joke, nor 
a disguise, nor a brand name. But who this lithe young man was, and where his cane-stalk legs carried him from or to, could never be known. No. Nor his name. (17-18)

As in Toni Morrison's first two novels, the central storyline of Song of Solomon is a quest for black identity. In Milkman's case it is a metaphorical struggle for life, for in order to become un-Dead he must somehow regain the "name that was real." Like Morrison's own project, Milkman's quest is to dis-cover the originary black logos and the mythical powers it holds.

Whereas Pecola Breedlove and Sula Peace seem sentenced from birth to a life of despair, Milkman seems fated from the first to achieve a greater destiny. $\mathrm{He}$ is the first black to be born in Mercy Hospital, and his entrance into the world is harkened by the ill-fated flight of Robert Smith, Southside's seemingly innocuous insurance salesman, who fashions himself a pair of blue silk wings and leaps to his death in an aborted attempt to fly, as the townspeople watch from below and Milkman's aunt, Pilate, sings:

O Sugarman done fly away

Sugarman done gone

Sugarman cut across the sky

Sugarman gone home. . . . (5)

With Mr. Smith's failed though spirited attempt to conquer logic and gravity, Milkman is welcomed somewhat auspiciously into the world, fated it would seem from birth to carry on this vision, this dream of flying back "home." Before he can fulfill his destiny, however, he must first recover his original name. To do so requires his first unlearning the white logos in order to recover the power imbued in a truly black identity.

His quest is an interpretive one, the fragment of the blues song which Pilate sings at the birth/death being the essential text which will lead him to his goal. But before he can learn to read this truly black text (and it is significant that the text is sung and therefore unwritten), he must first free himself from the linguistic bondage into which he was born. It is Pilate who becomes the boy's tutor in unlearning the white logos, who, even if she cannot free him, at least teaches him to love to be free. For Pilate is a figure who defies (white) logic and thereby challenges Milkman to drop the precepts of the white logos. Pilate's conjuring powers can be seen in the police station where, before Milkman's very eyes, she is able to transform herself into a withered hag, old and shrunken beyond her years. Furthermore, she possesses the power to communicate with the ghost of her dead father, although she continually misinterprets the spectral 
text which her father reveals in his visits from the other side of the grave, believing his only words, "Sing, sing," to be a command rather than an attempt to communicate to his daughter the now forgotten name of his bride.

The origin of Pilate's mystical powers would appear to lie in her possession of the original text of her name, inscribed on the piece of brown paper to which her father copied it, "as illiterate people do, [with] every curlicue, arch and bend in the letters" (18), that she keeps hanging from her ear in a small metal box. Again it is significant that her name has been written by a father who is illiterate, for it suggests that the original text to which Milkman's interpretive quest aspires is in fact pre-lexical and thus beyond the margins of the logos's field of power.

It is a quest which leads Milkman back to the small farming community of his father and Pilate's youth - a quest fed, at least initially, by both emotional need (ignited by Pilate's spiritual fostering) and material greed (inflamed by his father's tales of lost gold). However, once Milkman returns to Montour County and experiences the elation of being surrounded by folk who know, remember, and speak lovingly of his "people," he loses sight of his avarice and becomes completely absorbed in his quest to find his true name, his familial identity. Having escaped the narrow confines of his hometown, Milkman discovers that the first level of his misnaming is stripped away, and he becomes not "Milkman" but Macon Dead's son. It is here that he encounters the second tutor in his ongoing education to learn how to unread the white logos. Circe, like Pilate, is a conjurer figure, a keeper of spirits, a vessel of secrets from the past, a figure so utterly beyond the pale of the white logos that Milkman finds himself having to "take a chance" when he invokes "logic" to try to understand even her very existence:

Milkman struggled for a clear thought, so hard to come by in a dream: Perhaps this woman is Circe. But Circe is dead. This woman is alive. That was as far as he got, because although the woman was talking to him, she had to be dead. Not because of the wrinkles, and the face so old it could not be altve, but because out of the toothless mouth came the strong, mellifluent voice of a twenty-year-old girl. (242-43)

It is from Circe that Milkman learns the first names of his grandmother and grandfather, although Circe's knowledge, like Pilate's, is fragmented and unsure. Circe, however, is able to provide Milkman with the direction he needs in order to continue his quest, telling him that his grandfather's "people" came from "down around Culpepper somewhere. Charlemagne or something like that" (246). 
When Milkman arrives in the rural hill country of Virginia, in his ancestral home of Shalimar, the brand of the white logos is immediately evident to the town folk:

He hadn't found them fit enough or good enough to want to know their names, and believed himself too good to tell them his. They looked at his skin and saw it was as black as theirs, but they knew he had the heart of the white men who came to pick them up in trucks when they needed anonymous, faceless laborers. (269)

These toothless, poverty-stricken men who look sideways at him with scorn and attempt to slit his throat are, however, to be the teachers who erase the last vestiges of the white logos from Milkman and instill in him the knowledge necessary to be able to interpret the truly black text. Walking through the woods, following the bobbing lantern ahead as they trail the hounds, Milkman finally comes to realize the intuitive, almost primordial understanding which these men possess. For they are the keepers of a language unknown to him, a lexicon which has been lost beneath the veneer of civilization. As he struggles to keep up with the other hunters, trying to keep the light of the lantern in sight, he catches his first glimmer of understanding:

The men and the dogs were talking to each other. In distinctive voices they were saying distinctive, complicated things. . . . And the dogs spoke to the men .... It was all language. . . . No, it was not language; it was what there was before language. Before things were written down. Language in the time when men and animals did talk to one another . . . . (281)

There is a degree of authenticity to their use of language, to this inherently oral text, which Milkman had never previously imagined. And when the men in the mountains of Virginia finally shoot the bobcat from his perch atop the tree, Milkman is given his final initiation into the rites/rights/writes of his race which will enable him to interpret faithfully the semantic nuances of the truly black text. The men cajole him to reach into the carcass saying, " 'Don't get the lungs, now. Get the heart' " (286, emphasis added).

It is only by grasping the heart of the black idiom that Milkman is able to complete his interpretive quest. Only after this ritual has been performed does he realize that the song which he has heard the children of Shalimar singing over and over again, in what he takes to be an incessant, senseless children's game, is not, as he had initially thought, merely a "meaningless rhyme" but rather a fuller version of the essential text which Pilate misinterpreted as her father's telling her to "Sing, sing." Here, in the oral text passed on from generation to generation through children, Milkman learns that the interpretive trail which has led 
him from "Sugarman" to "Charlemagne" to "Shalimar" and finally to "Solomon" holds the secret of his true ancestry and revives a long subsumed desire in Milkman for flight. He returns to Southside to collect Pilate and the sack containing his grandfather's bones, whereupon they return together to the place in the mountains of Virginia where his great-grandfather leapt from the bounds of slavery into the arms of freedom.

With Milkman's leap Toni Morrison raises Afro-American fiction out of the black (w)hole, giving us instead a (w)holy black text. It is "whole" in the sense that Milkman has escaped the linguistic prison into which the drunken Yankee soldier wantonly threw his grandfather and all subsequent generations of his family. He has recovered that "name that was real" and with it an identity based on blackness as an affirmation, a source of wondrous power and heartfelt pride. By holy I mean to suggest that Morrison has been able to draw upon the soul of the spirituals, to bring out of the semantic shadows the true meaning of "home" in the blues passage "Sugarman done fly away ... I Sugarman gone home," and with it the true feelings of strength and joy which have always resided in the black logos and yet which have for too long remained confined to black (w)holes. I would also like to expand the conventional religious connotations of holy to include Toni Morrison's ability to raise folktales like the South Sea Islands' myth of the flying Africans on which the story of Milkman is based and the blues passages which provide Milkman with the oral history of his ancestor to a level worthy of being called sacred texts of the Afro-American tradition.

With the writing of Song of Solomon Toni Morrison thus successfully achieves her quest to overthrow the white logos, to escape the "glare of glazed separateness" which Pecola finds "lurking in the eyes of all white people" (Bluest Eye 42), making her feel small and ashamed of her blackness, and to free herself and her characters of the duplicity and power which the white landowner wielded over the ancestors of the Bottom. Morrison is effectively able to draw upon the power of the black logos to inscribe a black figure, a black reality upon the white page. It is a reality defined not by the mythos of (white) Western culture, the phenomenological "things-in-themselves" of Hegel or Heidegger or the naturalistic "realism" of Zola or Balzac, but instead a reality governed by the black logos-a magical realism. "Black people believe in magic," Toni Morrison has said, "it is part of our heritage" (Watkins 50). It is this heritage which Toni Morrison 
has drawn strength from in order to depict blackness as affirmation, presence, and good in the creation of a (w)holy black text.

\section{Notes}

1See Jacques Derrida, "White Mythology: Metaphor in the Text of Philosophy," Margins of Philosophy, trans. Alan Bass (Chicago: U of Chicago P, 1982). For Derrida's thoughts on the influence of logocentrism, see Jacques Derrida, Of Grammatology, trans. Gayatri Cakroavorty Splvak (Baltimore: Johns Hopkins UP, 1976).

2I do not mean to contend here that the element of black wholeness which Ellison and Wright describe is not without ironic overtones. Rather I wish to point out that Toni Morrison, still early on here in her quest for the (w)holy black text, at no time allows the reader to be content with considering these characters as whole.

\section{Works Cited}

Ellison, Ralph. Invistble Man. New York: Vintage, 1972.

Gates, Henry Louis, Jr. "Criticism in the Jungle." Black Literature and Literary Theory. Ed. Gates. New York: Methuen, 1984. 1-24.

Hughes, Langston. "Theme For English B." The Norton Anthology of Modern Poetry. Ed. Richard Ellmann and Robert O'Clair. New York: Norton, 1973. $640-41$.

Lee, Dorothy H. "The Guest for Self: Trumph and Fallure in the Works of Toni Morrison." Black Women Wrtters: A Critical Evaluation. Ed. Mari Evans. Garden City: Anchor, 1984. 346-59.

Morrison, Tont. The Bluest Eye. 1970. New York: Pocket, 1972.

-. Song of Solomon. New York: Knopf, 1977.

-. Sula. 1973. New York: Bantam, 1975.

Plato. Phaedrus. The Works of Plato. Trans. Benjamin Jowett. Ed. Irwin Edman. New York: Random, 1928.

Watkins, Mel. "Talk with Toni Morrison." New York Times Book Review 11 Sept. 1977: 50 . 